\title{
Cardiometabolic diseases and active aging - polypharmacy in control
}

\author{
Doenças cardiometabólicas e envelhecimento ativo - a polifarmácia no controle \\ Enfermedades cardiometabólicas y envejecimiento activo - la polimedicación en el control
}

Adriana Nancy Medeiros dos Santos' ORCID: 0000-0002-0705-9895

Dulcineia Rebecca Cappelletti Nogueira' ORCID: 0000-0002-1580-8390

Beatriz Aparecida Ozello Gutierrez' ORCID: 0000-0001-6901-6439

Rosa Yuka Sato Chubaci' ORCID: 0000-0001-9993-0889

Caroline Ribeiro de Borja Oliveira' ORCID: 0000-0003-3735-4016

'Universidade de São Paulo. São Paulo, São Paulo, Brazil.

How to cite this article:

Santos ANM, Nogueira DRC, Gutierrez BAO, Chubaci RYS, Oliveira CRB. Cardiometabolic diseases and active aging - polypharmacy in control. Rev Bras Enferm. 2020;73(2):e20180324. doi: http://dx.doi.org/10.1590/0034-7167-2018-0324

\author{
Corresponding Author: \\ Caroline Ribeiro de Borja Oliveira \\ E-mail: cborja@usp.br
}

EDITOR IN CHIEF: Antonio José de Almeida Filho ASSOCIATE EDITOR: Margarida Vieira

Submission: 06-05-2018Ａpproval: 11-29-2018

\begin{abstract}
Objectives: To estimate the prevalence of cardiometabolic diseases and their association with polypharmacy in elderly people at the University of the Third Age (Portuguese acronym: UnATI). Methods: A cross-sectional, descriptive, analytical study with 121 elderly patients. The prevalence ratio, Pearson's Chi-square test and Fisher's exact test were used as measures of association. Results: At the mean age of 68.3 , most elderly had at least one cardiometabolic disease $(82.6 \%)$, of which hypertension was the most prevalent (71.1\%), and consumed prescription drugs of continuous use $(92.6 \%)$. Almost half of the elderly (48.2\%) used combinations of drugs, which suggests a high cardiovascular risk. Polypharmacy due to prescription was observed in almost one-third (28.6\%) of the sample, associated with the use of antihypertensives $(p=0.004)$, antidiabetics $(p=0.000)$ or lipid-lowering agents $(p<0.000)$. Conclusions: Clinical guidelines recommend changes in lifestyle, but increased pharmacotherapy prevails in practice, which increases the risk of adverse events, especially in old age.
\end{abstract}

Descriptors: Comorbidity; Chronic Disease; Elderly; Polypharmacy; Pharmacological Treatment.

\section{RESUMO}

Objetivos: Estimar a prevalência de doenças cardiometabólicas e sua associação com polifarmácia em idosos da Universidade Aberta à Terceira Idade. Métodos: Estudo transversal, descritivo e analítico realizado com 121 idosos. A razão de prevalência e os testes Qui-quadrado de Pearson e Exato de Fisher foram utilizados como medidas de associação. Resultados: Com 68,3 anos de idade em média, a maioria dos idosos possuía pelo menos uma doença cardiometabólica $(82,6 \%)$, das quais a hipertensão era a mais prevalente $(71,1 \%)$, e consumia fármacos prescritos de uso contínuo $(92,6 \%)$. Quase metade deles $(48,2 \%)$ usava combinações de fármacos, o que sugere risco cardiovascular elevado. A polifarmácia advinda da prescrição foi observada em quase um terço $(28,6 \%)$ da amostra, associou-se ao uso de anti-hipertensivos $(p=0,004)$, antidiabéticos $(p=0,000)$ ou hipolipemiantes $(p<0,000)$. Conclusões: As diretrizes clínicas recomendam mudanças de estilo de vida, mas na prática, prevalece o incremento da farmacoterapia, o que eleva o risco de eventos adversos, sobretudo na velhice.

Descritores: Comorbidade; Doença Crônica; Idoso; Polimedicação; Tratamento Farmacológico.

\section{RESUMEN}

Objetivos: Estimar la prevalencia de enfermedades cardiometabólicas y su asociación con la polimedicación en ancianos de la Universidad de la Tercera Edad. Métodos: Estudio transversal, descriptivo y analítico realizado con 121 ancianos. Como medidas de asociación se utilizaron la razón de prevalencia y las pruebas chi-cuadrado de Pearson y exacta de Fisher. Resultados: Con 68,3 años de edad en promedio, la mayoría de los ancianos poseía por lo menos una enfermedad cardiometabólica $(82,6 \%)$, de las cuales la hipertensión era la más prevalente $(71,1 \%$ y y consumía medicación prescrita de uso continuo $(92,6 \%)$. Casi la mitad de ellos $(48,2 \%)$ usaba combinaciones de fármacos, lo que sugiere un alto riesgo cardiovascular. La polimedicación proveniente de la prescripción fue observada en casi un tercio $(28,6 \%)$ de la muestra, se asoció al uso de antihipertensivos $(\mathrm{p}=0,004)$, antidiabéticos $(p=0,000)$ o hipolipemiantes $(p<0,000)$. Conclusiones: Las directrices clínicas recomiendan cambios de estilo de vida, pero en la práctica, prevalece el incremento de la farmacoterapia, lo que eleva el riesgo de eventos adversos, sobre todo en la vejez.

Descriptores: Comorbilidad; Enfermedad Crónica; Ancianos; Polimedicación; Tratamiento Farmacológico. 


\section{INTRODUCTION}

The active aging policy proposed by the World Health Organization ${ }^{(1)}$ emphasizes that "aging well" is part of a collective construction that should be favored by public policies and opportunities of health access throughout the life course. Therefore, active aging is based on strengthening opportunities for participation and access to health and safety with a view to improving the quality of life as people get older. This policy is based on the assumption that for active and successful aging, opportunities must be created for individuals choosing healthy lifestyles and controlling their own health status ${ }^{(1-2)}$.

In fact, although the extension of life is an aspiration of any society, this is a real achievement only when quality is added to the additional years of life. Thus, actions aimed at the elderly must take into account functional capacity, the need for autonomy, participation, care and self-satisfaction. Furthermore, such actions must also open the way for the possibility of acting in various social contexts and assigning new meanings for life in advanced age fundamentally by encouraging prevention, care and integral health care $^{(3)}$.

The rapid aging of the Brazilian population has been accompanied by an increase in the prevalence of chronic diseases and use of drugs. In a population-based study conducted with elderly people in the city of São Paulo, the prevalence of polypharmacy (use of five or more drugs) reached $36 \%$ and was associated with the presence of hypertension and diabetes mellitus ${ }^{(4)}$. In an aging population, the strategic health indicator is not the presence or absence of disease, but rather the degree of functional capacity of individuals and the ability to conduct life independently and autonomously ${ }^{(5)}$.

Chronic diseases and their disabilities are not inevitable consequences of aging ${ }^{(3)}$. Likewise, old age and aging are not synonymous with disease, inactivity and contraction of development, and it is possible to maintain well-being and quality of life in old age ${ }^{(6-7)}$. Prevention is effective at any level, even in the later stages of life. The emphasis on prevention actions to slow the evolution of diseases and maintain functional capacity is the key to change the current reality ${ }^{(3)}$.

Between 2009 and 2015, pharmaceutical care workshops were offered at the University of the Third Age (Portuguese acronym: UnATI) of the University of São Paulo (USP). During these workshops, the UnATI was predominantly frequented by autonomous, socially active citizens with access to health services and consumers of medicines, especially those of continuous use, generally to treat their chronic diseases ${ }^{(8)}$.

In general, individuals attending UnATI have characteristics of a successful and active aging ${ }^{(9)}$. The elderly who maintain their independence and self-determination, that is, the capacity to exercise their autonomy, should be considered healthy, even if they present one or more chronic diseases ${ }^{(3)}$.

Most research on chronic diseases and polypharmacy in the elderly is conducted in health care units at primary health care level, ambulatory and hospital level with users and patients, or are population-based studies. In the context of UNATIs, research on the health of participants enables the identification of the profile, demands and risk factors for negative outcomes in an elderly population that remains active and participatory. This knowledge favors both the assessment of resources and elements that promote active old age, and the planning of actions aimed at maintaining functional capacity, autonomy and active aging.

The unfolding of these initiatives offers support that benefits the entire elderly population. In addition, these actions are in line with collective health as a social practice of transformative nature. This, in turn, is the framework for studies on health conditions, in which elements are sought to protect and promote health, quality of life and the social well-being of individuals and the community ${ }^{(10)}$. Social practice can be exercised in different organizations and institutions by various agents, within and outside spaces conventionally recognized as health sector ${ }^{(11)}$.

Cardiometabolic diseases (hypertension, diabetes, dyslipidemia and obesity) are highly prevalent, have a treatment profile in which the non-pharmacological approach (adopting a healthy lifestyle) requires perfectly delineable educational interventions that are applicable in the context of UnATIs. Lifestyle changes may improve the clinical picture of individuals affected by these diseases and reduce the need for pharmacological treatments, and if these are excessive, especially the elderly are exposed to the risk of adverse events.

Starting from the premise that knowing the target audience is strategic for the successful planning of efficient health promotion actions, the aim of this study was to investigate the prevalence of cardiometabolic diseases (CMD) - notably hypertension, diabetes, dyslipidemia, whose pharmacological treatment is common in the elderly - and their association with polypharmacy among UnATI participants.

\section{OBJECTIVE}

To investigate the prevalence of cardiometabolic diseases (CMD) and their association with polypharmacy among UnATI participants.

\section{METHODS}

\section{Ethical aspects}

This study was approved by the Ethics Committee of the School of Arts, Sciences and Humanities of the University of São Paulo.

\section{Design, place and period of the study}

Cross-sectional, descriptive, analytical quantitative study conducted at an UnATI in São Paulo. The purpose of the UnATI is to enable the elderly to deepen their knowledge in areas of their interest and exchange experiences with young people through workshops, lectures and disciplines of undergraduate courses offered every six months. All people aged 60 years and over may enroll at UnATI. The presentation of diplomas or certificates of education is not required for the enrollment in workshops and lectures. As UNATI participants respond to calls made by the programs, in general, their profile is characteristic of an active and successful aging ${ }^{(9)}$.

The present study was initiated with a pilot study to obtain a first picture of the level of health, that is, the diseases of UnATI participants, 
which indicated the need and/or the pertinence of implementing health promotion interventions in the UnATI. The period of collecting data from the elderly started in August 2016. This pilot study (unpublished data) included 60 people attending UnATI, and it was estimated that $80 \%$ of the elderly were on prescribed treatment for CMD (hypertension or diabetes or dyslipidemia). Therefore, these diseases were very prevalent, even in these active and participative elderly individuals. The large number of drugs used by the group also drew the attention. These results motivated the expansion of the study to reach a representative sample of this population.

\section{Population; inclusion and exclusion criteria}

At the beginning of collection ( $2^{\text {nd }}$ half of 2016), there were 243 elderly enrolled in UnATI activities. For the definition of sample size, were considered a confidence level of $95 \%$, standard error of $5 \%$ and the prevalence of $80 \%$ obtained in the pilot study. Based on these data, the defined sample size was 123 individuals.

All elderly people of both sexes aged 60 years or more enrolled in UnATI activities, who accepted to participate in the study and signed the Informed Consent (IC) form, met the inclusion criteria.

In the recruitment, individuals attending UnATI were approached in the campus and invited to participate in the study. After selecting those who fit the inclusion criteria, 121 elderly people composed the sample.

\section{Study protocol}

For data collection, was applied a previously structured form, in which were recorded data such as age, sex, type of health service used (public or private), prescribed drugs of continuous use and diagnoses.

\section{Analysis of results and statistics}

Although there is no consensus on the number of drugs that constitutes polypharmacy, which conceptually also encompasses self-medication (not considered in this study), it was defined as the continuous use of more than four drugs per individual ${ }^{(12)}$.

In the descriptive analysis of data, measures of central tendency (average) and dispersion (standard deviation) were determined for quantitative variables, and the distribution of frequency and percentages (absolute and relative frequencies) were determined for categorical variables.

The prevalence rate was calculated according to the following formula:

Prevalence $=$ number of cases in a given location and period $\times 100$ population of the same location and period

In order to estimate the prevalence of CMD, we considered the cases in which the elderly referred diagnoses and/or treatment of hypertension, diabetes mellitus and dyslipidemia. As lipidlowering agents may be prescribed for patients with certain risk factors regardless of cholesterol levels, in this study, was studied the prevalence of lipid-lowering agents rather than the diagnosis of dyslipidemia. In addition to the prevalence, the association between variables was estimated by bivariate analysis using the prevalence ratio (PR), confidence intervals (95\% Cl), Pearson's Chi-square test and Fisher's exact test, according to the number of cases, and the significance level of 5\%. Data analysis was performed in IBM SPSS Statistics.

\section{RESULTS}

The sample consisted of 121 people attending UnATI. The mean age of the sample was 68.3 years $(S D=6.1)$ and ranged from 60 to 84 years. Table 1 presents the prevalence of CMD and other variables studied. Most were female (75.2\%), users of private health services (71.9\%) and had at least one cardiometabolic disease (100 seniors; $82.6 \%, 95 \% \mathrm{Cl} 75.84-89,36)$. Hypertension was the most prevalent disease $(71.1 \%)$. There was a statistically significant association ( $p=0.031 ; P R=1.86,95 \% \mathrm{Cl} 1.07-3.24)$ between diabetes and the use of lipid-lowering agents.

The vast majority of the elderly (112 of them, $92.6 \%$ ) reported consuming prescribed drugs of continuous use. They used 3.45 drugs ( $S D=2.7)$ on average. Only nine elderly $(7.4 \%)$ reported not using any medication (prescribed and continuous). Among the others, this number ranged from 1 to 13 . Of these, 32 (28.6\%) used five or more (polypharmacy) (Table 1).

Table 1 - Prevalences and 95\% Cl of cardiometabolic diseases (CMD) and other variables studied in elderly subjects of UnATI, São Paulo, São Paulo, Brazil, 2017

\begin{tabular}{|c|c|c|}
\hline Variable & n (\%) & $95 \% \mathrm{Cl}$ \\
\hline \multicolumn{3}{|l|}{ Sex } \\
\hline Male & $30(24.8)$ & ) $20.0-29.6$ \\
\hline Female & $91(75.2)$ & ) $72.7-77.7$ \\
\hline \multicolumn{3}{|l|}{ Age group (years) } \\
\hline $60-69$ & $79(65.3)$ & $62.3-68.3$ \\
\hline$\geq 70$ & $42(34.7)$ & $26.2-43.2$ \\
\hline \multicolumn{3}{|l|}{ Health service ${ }^{a}$} \\
\hline Private & $87(71.9)$ & ) $63.9-79.9$ \\
\hline Public & $26(21.5)$ & ) $14.2-28.8$ \\
\hline \multicolumn{3}{|l|}{ Number of drugs prescribed ${ }^{b}$} \\
\hline 1 to 4 & $80(66.1)$ & ) $57.7-74.5$ \\
\hline$\geq 5$ & $32(26.4)$ & $18.6-34.3$ \\
\hline \multicolumn{3}{|l|}{ Conditions studied } \\
\hline Hypertension & $86(71.1)$ & $63.0-79.2$ \\
\hline Diabetes & $34(28.1)$ & ) $19.2-35.4$ \\
\hline Use of lipid-lowering agents & $36(29.8)$ & $21.7-38.0$ \\
\hline Hypertension and diabetes & $27(22.3)$ & ) $14.9-29.7$ \\
\hline Hypertension and use of lipid-lowering agents & $29(24.0)$ & $16.4-31.6$ \\
\hline Diabetes and use of lipid-lowering agents ${ }^{c}$ & $15(12.4)$ & $6.5-18.3$ \\
\hline Hypertension, diabetes and use of lipid-lowering agents & $13(10.7)$ & $5.2-12.2$ \\
\hline
\end{tabular}

Nota: ${ }^{a}$ Excluding the eight cases in which the question related to this variable was not answered; ${ }^{b}$ Excluding nine elderly people who reported not consuming prescription drugs of continuous use; ${ }^{c} p=0.031$, according to Pearson's Chi-square test; $\mathrm{Cl}$ - Confidence Interval.

Table 2 shows the association between CMD and the variables studied. There was a statistically significant association $(p<0.05)$ between the use of antihypertensive, antidiabetic or lipid-lowering drugs with polypharmacy, i.e., use of five or more drugs (Table 2).

There was a significant association $(p=0.019 ; \mathrm{PR}=2.07 ; 95 \% \mathrm{Cl}, 1.13-$ 3.77) between the use of lipid-lowering drugs and the pharmacological 
treatment of diabetes mellitus, regardless of the number of antidiabetic drugs used (monotherapy or drug combination). In the treatment of hypertension, only in cases of individuals who used combinations of more than one antihypertensive, there was a significant association $(p=0.001)$ with the use of lipid-lowering agents.

Table 2 - Association between cardiometabolic diseases and the variables studied in elderly subjects of UnATI, São Paulo, São Paulo, Brazil, 2017

\begin{tabular}{|c|c|c|c|}
\hline Variable & n (\%) & PR $(95 \% \mathrm{Cl})$ & $p$ value \\
\hline \multicolumn{4}{|l|}{ HYPERTENSION } \\
\hline $\begin{array}{l}\text { Sex } \\
\text { Male } \\
\text { Female }\end{array}$ & $\begin{array}{l}22(73.3) \\
64(70.3)\end{array}$ & $\begin{array}{c}1.04(0.57-2.18) \\
1.00\end{array}$ & 0.753 \\
\hline $\begin{array}{l}\text { Age group (years) } \\
\quad 60-69 \\
\geq 70\end{array}$ & $\begin{array}{l}56(70.9) \\
30(71.4)\end{array}$ & $\begin{array}{c}1.00 \\
1.01(0.79-1.28)\end{array}$ & 0.950 \\
\hline $\begin{array}{l}\text { Health service }{ }^{b} \\
\text { Private } \\
\text { Public }\end{array}$ & $\begin{array}{l}65(74.7) \\
15(57.7)\end{array}$ & $\begin{array}{c}1.29(0.91-1.84) \\
1.00\end{array}$ & 0.094 \\
\hline $\begin{array}{l}\text { Prescribed drugs } \\
\quad 1 \text { to } 4 \\
\geq 5\end{array}$ & $\begin{array}{l}57(64.0) \\
29(90.6)\end{array}$ & $\begin{array}{c}1.00 \\
1.42(1.17-1.71)\end{array}$ & 0.004 \\
\hline \multicolumn{4}{|l|}{ DIABETES } \\
\hline $\begin{array}{l}\text { Sexo } \\
\text { Male } \\
\text { Female }\end{array}$ & $\begin{array}{c}7(23.3) \\
27(29.7)\end{array}$ & $\begin{array}{c}1.00 \\
1.27(0.62-2.62)\end{array}$ & 0.503 \\
\hline $\begin{array}{l}\text { Age group (years) } \\
\quad 60-69 \\
\geq 70\end{array}$ & $\begin{array}{l}22(27.8) \\
12(28.6)\end{array}$ & $\begin{array}{c}1.03(0.80-1.28) \\
1.00\end{array}$ & 0.933 \\
\hline $\begin{array}{l}\text { Health service }{ }^{b} \\
\text { Private } \\
\text { Public }\end{array}$ & $\begin{array}{l}22(25.3) \\
7(26.9)\end{array}$ & $\begin{array}{c}1.00 \\
1.06(0.79-1.33)\end{array}$ & 0.867 \\
\hline $\begin{array}{l}\text { Prescribed drugs } \\
\quad 1 \text { to } 4 \\
\geq 5\end{array}$ & $\begin{array}{l}17(19.1) \\
17(53.1)\end{array}$ & $\begin{array}{c}1.00 \\
2.78(1.63-4.76)\end{array}$ & 0.000 \\
\hline \multicolumn{4}{|c|}{ USE OF LIPID-LOWERING AGENTS } \\
\hline $\begin{array}{l}\text { Sex } \\
\text { Male } \\
\text { Female }\end{array}$ & $\begin{array}{c}7(23.3) \\
29(31.9)\end{array}$ & $\begin{array}{c}1.00 \\
1.37(0.67-2.79)\end{array}$ & 0.375 \\
\hline $\begin{array}{l}\text { Age group (years) } \\
\quad 60-69 \\
\geq 70\end{array}$ & $\begin{array}{l}25(31.6) \\
11(26.2)\end{array}$ & $\begin{array}{c}1.21(0.66-2.21) \\
1.00\end{array}$ & 0.532 \\
\hline $\begin{array}{l}\text { Health service }{ }^{b} \\
\text { Private } \\
\text { Public }\end{array}$ & $\begin{array}{l}28(32.2) \\
7(26.9)\end{array}$ & $\begin{array}{c}1.20(0.59-2.41) \\
1.00\end{array}$ & 0.611 \\
\hline $\begin{array}{l}\text { Prescribed drugs } \\
1 \text { to } 4 \\
\geq 5\end{array}$ & $\begin{array}{l}16(18.0) \\
20(62.5)\end{array}$ & $\begin{array}{c}1.00 \\
3.47(2.07-5.84)\end{array}$ & 0.000 \\
\hline
\end{tabular}

Note: ${ }^{a}$ Excluding the eight cases in which the question related to this variable was not answered, ${ }^{b}$ Excluding the nine elderly people who reported not consuming prescription drugs of continuous use; 'Pearson's Chi-square test or Fishers Exact test; RP - Prevalence Ratio; Cl-Confidence Interval.

Altogether, 54 elderly people (48.2\% of those who consumed drugs) used combinations of antihypertensive, antidiabetic or lipid-lowering drugs. All cases of prescribed polypharmacy included at least one of these combinations.

In total, were reported 25 different antihypertensives. The most commonly reported were losartan, hydrochlorothiazide, atenolol, amlodipine and enalapril (Table 3). Four seniors reported not using any and the others used between one and four antihypertensives.
Table 3 - Antihypertensive, antidiabetic and lipid-lowering agents used by elderly subjects of UnATI, São Paulo, São Paulo, Brazil, 2017

\begin{tabular}{|c|c|}
\hline ANTIHYPERTENSIVES & $n(\%)^{a}$ \\
\hline Angiotensin II receptor blockers & $43(52.4)$ \\
\hline Losartan & $40(48.8)$ \\
\hline Olmesartan & $2(2.4)$ \\
\hline Valsartan & $1(1.2)$ \\
\hline Diuretics & $32(39.0)$ \\
\hline Hydrochlorothiazide & $24(29.3)$ \\
\hline Furosemide & $2(2.4)$ \\
\hline Indapamide & $2(2.4)$ \\
\hline Amiloride & $2(2.4)$ \\
\hline Chlorthalidone & $1(1.2)$ \\
\hline Spironolactone & $1(1.2)$ \\
\hline Betablockers & $32(39.0)$ \\
\hline Atenolol & $18(22.0)$ \\
\hline Carvedilol & $6(7.3)$ \\
\hline Propranolol & $3(3.7)$ \\
\hline Metoprolol & $3(3.7)$ \\
\hline Nebivolol & $1(1.2)$ \\
\hline Sotalol & $1(1.2)$ \\
\hline Angiotensin-converting enzyme inhibitor & $23(28.0)$ \\
\hline Enalapril & $13(15.9)$ \\
\hline Captopril & $7(8.5)$ \\
\hline Ramipril & $2(2.4)$ \\
\hline Benazepril & $1(1.2)$ \\
\hline Calcium channel blockers & $21(25.6)$ \\
\hline Amlodipine & $17(20.7)$ \\
\hline Nifedipine & $3(3.7)$ \\
\hline Levamlodipine & $1(1.2)$ \\
\hline Central acting adrenergic inhibitors & $4(4.9)$ \\
\hline Clonidine & $3(3.7)$ \\
\hline Methyldopa & $1(1.2)$ \\
\hline Direct vasodilators & $1(1.2)$ \\
\hline Hydralazine & $1(1.2)$ \\
\hline THERAPEUTIC REGIMEN & n (\%) \\
\hline Monotherapy & $36(43.9)$ \\
\hline Association of two drugs & $27(32.9)$ \\
\hline Association of three or four drugs & $19(23.2)$ \\
\hline ANTIDIABETICS & n (\%) \\
\hline Biguanides & $22(73.3)$ \\
\hline Metformin & $22(73.3)$ \\
\hline Sulfonylureas & $7(23.3)$ \\
\hline Gliclazide & $4(13.3)$ \\
\hline Glibenclamide & $2(6.7)$ \\
\hline Glimepiride & $1(3.3)$ \\
\hline Gliptins & $6(20.0)$ \\
\hline Vidagliptin & $3(10.0)$ \\
\hline Sitagliptin & $2(6.7)$ \\
\hline Linagliptin & $1(3.3)$ \\
\hline Insulin & $3(10.0)$ \\
\hline Inhibitors of sodium-glucose cotransporter 2 (SGLT2) & $1(3.3)$ \\
\hline Dapagliflozin & $1(3.3)$ \\
\hline THERAPEUTIC REGIMEN & n (\%) \\
\hline Monotherapy & $19(63.3)$ \\
\hline Association of two drugs & $6(20.0)$ \\
\hline Association of three drugs & $4(13.3)$ \\
\hline
\end{tabular}


Table 1 (concluded)

\begin{tabular}{lc}
\hline LIPID-LOWERING AGENTS & $\mathbf{n}(\%)$ \\
\hline Statins & $34(94.4)$ \\
Simvastatin & $23(63.9)$ \\
Atorvastatin & $7(19.4)$ \\
Rosuvastatin & $4(11.1)$ \\
Fibrates & $4(11.1)$ \\
Ciprofibrate & $3(8.3)$ \\
Fenofibrate & $1(2.8)$ \\
Bezafibrate & $1(2.8)$ \\
Others & $1(2.8)$ \\
Ezetimibe & $1(2.8)$ \\
\hline THERAPEUTIC REGIMEN & $\mathbf{n}(\%)$ \\
\hline Monotherapy & $32(88.9)$ \\
Association of two drugs & $4(11.1)$ \\
\hline
\end{tabular}

Note: ${ }^{a}$ The percentages are relative to the total number of elderly people who reported using antihypertensives (82 subjects); ${ }^{6}$ The percentages are relative to the total number of elderly people who reported using antidiabetics (30 subjects).

Regarding the therapeutic regimen for hypertension, 36 elderly patients (43.9\% of 82 patients undergoing hypertension treatment) used monotherapy (Table 3); 18 of them used losartan ( $50 \%$ of cases of antihypertensive monotherapy). Therefore, 46 elderly $(56.1 \%)$ out of the 82 undergoing pharmacological hypertension treatment used a combination of antihypertensives. The most common combinations ( 12 elderly, $44.4 \%$ of cases of two-drug combination) were angiotensin II receptor blockers with diuretics or beta-blockers.

For the treatment of diabetes mellitus, were identified nine drugs (Table 3). Metformin was the most prevalent. Four elderly subjects who reported having the diagnosis of diabetes did not use any antidiabetics; the others consumed between one and three. The use of monotherapy was identified in 19 seniors $(63.3 \%$ of those who consumed antidiabetics). Of these, 15 (78.9\%) used metformin. Six elderly subjects (20.0\%) used an association of two antidiabetic drugs, and another four (13.3\%) used an association of three. Most combinations (7; $70.0 \%$ of them) involved the association of metformin with sulfonylureas and gliptins. Thus, 11 elderly (36.7\%) out of the 30 undergoing pharmacological diabetes treatment used a combination of antidiabetics.

Seven lipid-lowering agents were reported (Table 3). The most prevalent was simvastatin, mainly in the form of monotherapy (20 cases, $55.6 \%$ of those who used lipid-lowering drugs). Only four elderly subjects used a combination of two lipid-lowering agents.

\section{DISCUSSION}

Most (86.6\%) participants in the study had a diagnosis of CMD, and almost half (48.2\%) used combinations of drugs instead of monotherapy to treat those diseases. There was a significant association $(p<0.05)$ between the use of lipid-lowering drugs and pharmacological treatment of diabetes, regardless of the number of antidiabetic drugs consumed (monotherapy or drug combination). Regarding hypertension treatment, only cases of individuals using combinations of more than one antihypertensive were significantly associated with the use of lipid-lowering agents.

These results may be related to the therapeutic regimen adopted for each morbidity. The $7^{\text {th }}$ Brazilian Guideline of Arterial
Hypertension ${ }^{(13)}$ considers monotherapy as the initial antihypertensive strategy for patients with stage 1 arterial hypertension (systolic blood pressure 140-159 and diastolic blood pressure 90-99) with low and moderate cardiovascular risk, in spite of the statement that most patients will require the association of drugs ${ }^{(13)}$. The use of lipid-lowering agents is more common in cases of higher cardiovascular risk, where antihypertensive combinations are used. This fact may at least in part, justify the association between the use of lipid-lowering drugs and combinations of more than one antihypertensive drug found in this study. These data also suggest that elderly patients who used antihypertensive and lipid-lowering combinations at the same time have a higher cardiovascular risk.

There is evidence that individuals affected by diabetes mellitus are at two to four times higher risk for cardiovascular disease compared to non-diabetics. Dyslipidemia, a major risk factor for atherothrombotic diseases, has toxic effects on beta-pancreatic cells (lipotoxicity) and, in the presence of hyperglycemia, cardiovascular risk is potentially increased. Atherosclerotic diseases, which comprise coronary artery disease, peripheral vascular disease, and cerebrovascular disease account for $75 \%$ of deaths in individuals with type 2 diabetes mellitus. Of these, $50 \%$ of fatal cases result from coronary artery disease ${ }^{(14)}$.

The statistically significant association $(p<0.05)$ between the use of lipid-lowering drugs with diabetes and hypertension explains the also significant association of these treatments and diagnoses with polypharmacy (use of five or more drugs). As in most cases, treatment with lipid-lowering drugs is used as monotherapy, and its statistical association with prescribed polypharmacy was expected to be related to dyslipidemia-related morbidities, since these increase the number of drugs used by the same individual.

Hypertension and diabetes also had significant and isolated association $(p<0.05)$ with polypharmacy. Their commonly combined therapeutic regimen (use of more than one antihypertensive or more than one antidiabetic per individual) composed the totality of polypharmacy cases identified in this study.

In hypertension treatment, were identified 19 cases $(23.2 \%$ of the total sample) of use of three or more antihypertensive drugs, a number that contributes substantially to polypharmacy. This therapeutic regimen is recommended by the $7^{\text {th }}$ Brazilian Guideline of Arterial Hypertension ${ }^{(13)}$. According to the guideline, the association of three or more drugs is recommended if treatment response is inadequate and blood pressure control goals are not achieved with two drugs. In case of partial result without side effects, the dose of the initial combination may be increased, or another antihypertensive of another class may be added. The guideline also adds that if blood pressure remains uncontrolled at the maximum possible doses, other antihypertensive agents should be associated ${ }^{(13)}$. The relationship between these guidelines and the findings in this study presuppose that pharmacological increment and therefore, polypharmacy, is the form of control adopted for cardiometabolic diseases.

The recommended therapeutic regimens explain the polypharmacy observed in this study, which is prescribed and continuous. In general, studies on polypharmacy are not limited to prescribed pharmacotherapy and also consider self-medication and sporadic drugs. The purpose in the present study was limiting 
the analysis to the prescribed polypharmacy, in the search for a better understanding of the contribution of prescriptions to the phenomenon of polypharmacy. This indicates that if we included the prescribed drugs of sporadic use and self-medication, the values presented here on the number of drugs used per individual would be higher.

In the elderly, polypharmacy is associated with poor adherence to treatment regimens, drug interactions, medication errors, and adverse drug reactions. It can lead to falls, fractures, confusion, delirium, visits to emergency/urgency services and hospitalization. It also generates direct and indirect costs, such as those related to the medicine and its health damages that impact on both individuals' personal economy and the health system ${ }^{(15)}$.

Polypharmacy in old age is a common and well documented problem. In the city of São Paulo, the prevalence of polypharmacy was estimated at $36 \%$ in a study involving 1,115 elderly individuals over 65 years of age living in the city and, as in the present study, was associated with the presence of hypertension and diabetes ${ }^{(4)}$. These findings remain in the national panorama. A recent study, conducted with data from the National Survey on Access, Use and Promotion of Rational Use of Medications analyzed variations in the prevalence of continuous use of drugs by elderly people living in Brazil, according to its possible association with the most prevalent chronic diseases. In the analysis based on a national probabilistic sample $(n=41,433)$, the prevalence of at least one medication of continuous use among the elderly was $93.0 \%$, and the drugs for hypertension or heart disease and cholesterol control accounted for $63 \%$ of reports. Polypharmacy was present in $18 \%$ of elderly subjects, and was also higher among individuals with diabetes and heart disease ${ }^{(16)}$. The results of these populationbased studies are similar to those obtained in the present study, which was conducted with a sample of active and participatory elderly subjects.

In the international scenario, even in developed countries, the addition of more drugs is often the form of control of cardiometabolic diseases, too. A study of 214 elderly people in Canada also found an association between polypharmacy and more intensive pharmacological treatments to treat hypertension and diabetes. However, in this study, the sample consisted of very fragile and institutionalized elderly people ${ }^{(17)}$.

Although in the present study, were identified 41 drugs prescribed for the cardiometabolic diseases studied (hypertension, diabetes and use of lipid-lowering drugs), there was a predominance of the prescribed use of certain drugs, namely: losartan, hydrochlorothiazide, simvastatin, metformin, atenolol, amlodipine and enalapril. In general, this predominance is based on accumulated evidence on safety and efficacy. Metformin, for example, is generally the antidiabetic of choice because of its efficacy in glycemic control, low incidence of adverse effects, proven safety and favorable impact on weight gain. However, from the time of diagnosis, treatment should include changes in lifestyle $\mathrm{e}^{(18)}$.

The prescriber's choice of pharmacological treatment is also based on patients' socioeconomic conditions. The most prevalent drugs in this study are part of the Municipal List of Essential Drugs and therefore, can be obtained free of charge. Although most elderly people in this study use private health services, the free dispensation is not limited to public service users. As the elderly tend to consume large numbers of medicines, they usually choose to obtain through access programs.

In the study based on data from the National Survey on Access, Use and Promotion of Rational Use of Medications ${ }^{(16)}$, a total of ten drugs (hydrochlorothiazide, losartan, simvastatin, metformin, enalapril, captopril, atenolol, amlodipine, acetylsalicylic acid and glibenclamide) accounted for half of reports. As is well known, these drugs are used in the treatment of the CMD discussed in the present work. The exception is acetylsalicylic acid, since the present study was limited to considering the use of antihypertensive, antidiabetic and lipid-lowering agents. Ramos et al. ${ }^{(16)}$ emphasized that the ten most consumed drugs are part of the National List of Essential Medicines (Portuguese acronym: RENAME) can be obtained at no cost to patients, are part of the Basic Component of Pharmaceutical Care, whose dispensation is in health units of SUS, and are part of the Popular Pharmacy Program.

Among medications available free of charge through government access programs, some are considered potentially inappropriate for the elderly. In the present study, was identified the use of some of them, namely: the antidiabetic glibenclamide that may cause severe prolonged hypoglycemia in the elderly, and clonidine and methyldopa antihypertensive agents that subject the elderly to a high risk of central adverse effects ${ }^{(19)}$. Potentially inappropriate drugs should be avoided or used with caution in this age group. In the prescription of these drugs, should be considered the following: the risk-benefit relationship, availability of alternative agents and non-pharmacological resources, the choice of the lowest required dose, potential drug interactions and the monitoring of effects in the patient ${ }^{(20)}$.

Older people are more vulnerable to adverse events than young individuals, even when prescribed drugs are supposedly more appropriate for the age group. According to the $7^{\text {th }}$ Brazilian Guideline of Arterial Hypertension ${ }^{(13)}$, non-pharmacological treatment based on a healthy lifestyle should be encouraged at all stages of high blood pressure. Despite simple and apparently easy to adopt, there is great resistance to this practice, since it implies changing old habits. The main guidelines for lifestyle modification (LSM) that have proven effect on blood pressure reduction and minimization of cardiovascular risk are: physical activity, smoking cessation, weight loss (when high), and a balanced diet (low in salt, high in fruits and vegetables). This therapy is recommended for the elderly, and moderate salt reduction in the diet is beneficial. This LSM is one of the best studied as an intervention for blood pressure control. The reduction of blood pressure is usually more significant when we take into account older adults ${ }^{(13)}$. Interventions aimed at promoting the adoption of healthier lifestyles are practiced in several health care units, and in the UnATI. However, the high prevalence of chronic diseases and polypharmacy demonstrates the need to expand these actions and promote greater participation.

In addition to actions for promoting a healthy lifestyle, those aimed at promoting adherence to the prescribed pharmacological treatment are essential, and although this is a paramount and strategic aspect for successful treatments, it has been underestimated. In spite of so many efforts, society's access to medical services, the conduct of necessary examinations and procedures, 
and prescription of a safe and effective treatment, after the longawaited prescription, little attention is paid to patients' compliance, without which all previous procedures may have been in vain. The progression and worsening of diseases that results in the need for association/combination of drugs, is largely due to lack of adherence in the early stages of the disease. Patients often initiate treatment with monotherapy and do not adhere adequately to it and/or the necessary lifestyle changes. The lack of adherence leads to disease aggravation and consequently, to the need for combining drugs. From another perspective, the lack of adherence to monotherapy may also lead the prescriber to misinterpret the therapy ineffectiveness as a need for drug combination. This scenario is perfectly predictable given the known difficulties that compromise communication, trust and complicity between patients and professionals.

The approaches of a healthy lifestyle, treatment adherence, means of access to prescribed treatment and communication between patients and professionals, can be successfully addressed through educational actions. Such actions should be carefully planned and executed. The Brazilian Society of Diabetes guidelines states that "the aim of the entire educational approach must be to transform diabetes into an integral part of the patient's life, not in a controlling and threatening way"(14). This assertion applies not only to those with diabetes, but to every individual. It is crucial that patients feel they are not being controlled, but rather taking control of their condition.

It is also very important to share with individuals the fundamentals that justify the directions and instructions they receive. In the pharmaceutical care workshops at the UnATI, University of São Paulo, it is well-known that participants begin to adhere to instructions and follow them when they know the reasons on which they are based. Patients are autonomous in decision making, and if they consider the instructions irrelevant, they may disregard them ${ }^{(21)}$.

\section{Limitations of the study}

This study has some limitations, such as the size of the sample, which restricted the deepening of the analysis of potential associations between variables. In addition, since this is a crosssectional study, the direction of associations identified cannot be determined, which would be feasible in follow-up studies. The fact of using self-reported information based only on participants' reports is also limiting because it introduces a memory bias. Since polypharmacy was characterized only in cases of use of five or more prescribed drugs of continuous use, if possible forgotten drugs and those consumed by self-medication were included, the prevalence of polypharmacy would be higher in the studied group. Information about participants' lifestyle was not collected to confront the presented data, and this approach shall be incorporated in the continuity of this investigation.

Studies of this nature may be more complete and informative when conducted in partnership with participants' health services. In the case of this study, this integration would be challenging, since the elderly have access to different and diverse services, mainly private services. On the other hand, as a practice, collective health materializes not only within but also outside spaces recognized as health sector, in different organizations and institutions and by the action of several agents ${ }^{(11)}$.

\section{Contributions to the health area}

This study was motivated by the high prevalence of the cardiometabolic diseases studied and because they have a treatment profile in which the non-pharmacological approach (adoption of a healthy lifestyle) requires educational interventions that are perfectly applicable in the context of UnATIs. Since lifestyle changes can improve the clinical picture of individuals affected by these diseases and reduce the need for pharmacological treatments, in this study, we sought to know the profile of the target audience in order to favor the planning of efficient collective health promotion actions, guide these actions and, above all, point out their relevance. The implementation of actions based on the findings presented here will open opportunities for wider, appropriate, informative and in-depth research.

This logic has the collective health as reference. This is a field of theories and practices that seeks in the objective reality the means and instruments of intervening in the epidemiological profiles of the population of a given territory by understanding their constitution through interpenetrating totalities, namely the structural, particular and singular dimensions ${ }^{(22)}$. In the context of collective health, work processes operate with the purpose of transforming epidemiological profiles, promoting the development of healthy life, and instruments that support the construction of qualified practices that respond to social groups' needs. These instruments are built to enable the capture of the reality of life and health and contribute to reading the needs of progress and sustainability of intervention projects that will produce the desired impact: attending the social groups that need the most support in order that they conquer autonomy for living life with quality and perspective of self-care in the context of equity and social justice ${ }^{(23)}$.

\section{CONCLUSION}

Since most research on chronic diseases and polypharmacy in the elderly is conducted in health care units with users and patients, or are population-based studies, the present study sought to estimate the prevalence of CMD and its association with polypharmacy and therapeutic regimen in elderly participants of the UnATI with the perspective of guiding the planning of actions that aim to maintain functional capacity and active aging in this population. In this study, most elderly individuals had CMD and half used combinations of drugs to treat them, which is often due to the identification of high cardiovascular risk, and polypharmacy was identified in almost one third of individuals. However, these elderly people present characteristics of a successful and active aging, since they participated of UnATI activities and responded to their request ${ }^{(9)}$.

In this study, there was a significant association between the polypharmacy, the treatment of the studied cardiometabolic diseases and the use of drug combinations - instead of monotherapy. The prescription of drug combinations for a same condition is often the result of worsening of the clinical picture, which is a usually avoidable situation. 
These results point to the need for investments in actions to maintain the functional capacity of these active and participative elderly people, in spite of their diagnoses of diseases. The continual worsening of conditions, which is already prevalent, and the functional losses that compromise autonomy and the capacity to participate must be avoided.

The guidelines adopted for the pharmacological treatment of these individuals are supported by clinical guidelines that also recommend changes in lifestyle, even though the increase in pharmacotherapy prevails in practice, since it leads to a higher risk of adverse events and negative outcomes, especially in old age. The worsening of diseases and the consequent need for polypharmacy may also result from the lack of adherence to treatment in the early stages of the disease. In order to preserve functional capacity and an active old age, are required actions for the promotion of a healthy lifestyle, adherence to treatment and others with the aim to empower individuals and control their condition.

\section{REFERENCES}

1. Organização Pan-Americana de Saúde (OPAS). Envelhecimento ativo: uma política de saúde [Internet]. Brasília: OPAS; 2005 [cited 2018 May 04]. Available from: http://bvsms.saude.gov.br/bvs/publicacoes/envelhecimento_ativo.pdf

2. Silva HS, Lima AMM, Galhardoni R. Envelhecimento bem-sucedido e vulnerabilidade em saúde: aproximações e perspectivas. Interface (Botucatu). 2010;14(35):867-77. doi: 10.1590/S1414-32832010005000034

3. Veras R. Population aging today: demands, challenges and innovations. Rev Saúde Pública. 2009;43(3):548-54. doi: 10.1590/ S0034-89102009005000025

4. Carvalho MFC, Romano-Lieber NS, Bergsten-Mendes G, Secoli SR, Ribeiro E, Lebrão ML, et al. Polypharmacy among the elderly in the city of São Paulo, Brazil - SABE Study. Rev Bras Epidemiol. 2012;15(4):817-27. doi: 10.1590/S1415-790X2012000400013

5. Veras RP. Chronic disease management: mistaken approach in the elderly. Rev Saúde Pública. 2012;46(6):929-34. doi: 10.1590/ S0034-89102012000600001

6. Lima AMM, Silva HS, Galhardoni R. Successful aging: paths for a construct and new frontiers. Interface (Botucatu). 2008;12(27):795-807. doi: $10.1590 /$ S1414-32832008000400010

7. Neri AL. Palavras-chave em gerontologia. Campinas: Alínea; 2008.

8. Borja-Oliveira CR. Pill organizers and pill cutters: risks and limitations. Rev Saúde Pública. 2013;47(1):123-7. doi: 10.1590/ S0034-89102013000100016

9. Cachioni M, Delfino LL, Yassuda MS, Batistoni SST, Melo RC, Domingues MARC. Subjective and psychological well-being among elderly participants of a University of the Third Age. Rev Bras Geriatr Gerontol. 2017;20(3):340-52. doi: 10.1590/1981-22562017020.160179

10. Arreaza ALV, Moraes JC. Vigilância da saúde: fundamentos, interfaces e tendências. Ciênc Saúde Colet. 2010;15(4):2215-28. doi: 10.1590/ S1413-81232010000400036

11. Paim JS, Almeida Filho N. Saúde coletiva: uma "nova saúde pública" ou campo aberto a novos paradigmas? Rev Saúde Pública. 1998;32(4):299-316. doi: 10.1590/S0034-89101998000400001

12. Gnjidic D, Hilmer SN, Blyth FM, Naganathan V, Waite L, Seibel MJ, et al. Polypharmacy cutoff and outcomes: five or more medicines were used to identify community-dwelling older men at risk of different adverse outcomes. J Clin Epidemiol. 2012;65(9):989-95. doi: 10.1016/j. jclinepi.2012.02.018

13. Sociedade Brasileira de Cardiologia (SBC). 7a Diretriz Brasileira de Hipertensão Arterial. Arq Bras Cardiol [Internet]. 2016 [cited 2018 May 04];107(3 Supl. 3):1-83. Available from: http://publicacoes.cardiol.br/2014/diretrizes/2016/05_HIPERTENSAO_ARTERIAL.pdf

14. Oliveira JEP, Sergio V, organizadores. Diretrizes da Sociedade Brasileira de Diabetes (2015-2016) [Internet]. São Paulo: A.C. Farmacêutica; 2016 [cited 2018 May 04]. Available from: http://www.diabetes.org.br/profissionais/images/docs/DIRETRIZES-SBD-2015-2016.pdf

15. Pesante-Pinto JL. Clinical Pharmacology and the Risks of Polypharmacy in the Geriatric Patient. Phys Med Rehabil Clin N Am. 2017;28(4):73946. doi: 10.1016/j.pmr.2017.06.007

16. Ramos LR, Tavares NUL, Bertoldi AD, Farias MR, Oliveira MA, Luiza VL, et al. Polypharmacy and Polymorbidity in Older Adults in Brazil: a public health challenge. Rev Saúde Pública. 2016;50(suppl 2):9s. doi: 10.1590/s1518-8787.2016050006145

17. McCracken R, McCormack J, McGregor MJ, Wong ST, Garrison S. Associations between polypharmacy and treatment intensity for hypertension and diabetes: a cross-sectional study of nursing home patients in British Columbia, Canada. BMJ Open. 2017;7(8):e017430. doi: 10.1136/bmjopen-2017-017430

18. Rhee SY, Kim HJ, Ko SH, Hur KY, Kim NH, Moon MK, et al. Monotherapy in Patients with Type 2 Diabetes Mellitus. Diabetes Metab J. 2017;41(5):349-56. doi: 10.4093/dmj.2017.41.5.349

19. Oliveira MG, Amorim WW, Oliveira CRB, Coqueiro HL, Gusmão LC, Passos LC. Consenso Brasileiro de Medicamentos Potencialmente Inapropriados para Idosos. Geriatr Gerontol Aging [Internet]. 2016 [cited 2018 May 4];10(4):168-81. Available from: http://ggaging.com/ details/397/pt-BR/brazilian-consensus-of-potentially-inappropriate-medication-for-elderly-people

20. Assato CP, Borja-Oliveira CR. Psicofármacos potencialmente inapropriados para idosos. Estud Interdiscipl Envelhec [Internet]. 2015 [cited 2018 May 04];20(3):687-701. Available from: www.seer.ufrgs.br/RevEnvelhecer/article/download/38548/36679 
21. Borja-Oliveira CR. A influência da água mineral sobre a absorção dos bisfosfonatos orais. Rev Salusvita [Internet]. 2017 [cited 2018 May 04];36(2):565-85. Available from: https://secure.usc.br/static/biblioteca/salusvita/salusvita_v36_n2_2017_art_13.pdf

22. Egry EY, Fonseca RMGS, Oliveira MAC. Ciência, Saúde Coletiva e Enfermagem: destacando as categorias gênero e geração na episteme da práxis. Rev Bras Enferm. 2013;66:119-33. doi: 10.1590/S0034-71672013000700016

23. Bertolozzi MR, Nichiata LYI, Takahashi RF, Ciosak SI, Hino P, Val LF, et al. The vulnerability and the compliance in Collective Health. Rev Esc Enferm USP [Internet]. 2009;43 (spe 2):1326-30. doi: 10.1590/S0080-62342009000600031. 